УДК 373.053 .4

DOI:

Христина Марія Карвацька, магістр кафедри початкової та дошкільної освіти Львівського начіонального університету імені Івана Франка

\title{
ПРОБЛЕМА РОЗВИТКУ АДЕКВАТНОЇ САМООЩІНКИ ДІТЕЙ СТАРШОГО ДОШКІЛЬНОГО ВІКУ У ПСИХОЛОГО-ПЕДАГОГІЧНИХ ДОСЛІДЖЕННЯХ
}

Стаття присвячена аналізу психолого-педагогічних досліджень щзодо формування адекватноі самооцінки дитини у старшому дошкільному віці. Аналіз та узагальнення підходів і концепцій до вивчення проблеми самооцінки дошкільників свідчить, щзо дошкільний вік є сприятливим для формування самооцінки дитини і виступає важливою передумовою зародження ї̈ адекватності. У старшому домкільному віиі потреба дитини у оцінці дорослого велика, однак самооцінка дитини починає опиратися на результати $i$ висновки, які дитина отримує в індивідуальному досвіді.

Ключові слова: стариий дошкільний вік; адекватна самооцінка; розвиток самооиінки; психологопедагогічні дослідження.

Jim. 9.

Chrystyna Mariya Karvatska, Master Student of the Primary and Preschool Education Department Lviv Ivan Franko National University

\section{PROBLEM OF DEVELOPMENT OF ADEQUATE SELF-ASSESSMENT OF CHILDREN OFTHE SENIOR PRESCHOOLAGE IN PSYCHOLOGICAL AND PEDAGOGICAL RESEARCHES}

The article is devoted to the analysis of psychological and pedagogical researches concerning the formation of the child's self-esteem in the senior preschool age. The analysis and generalization of approaches and concepts to the study of the problem of self-esteem of preschool children shows that pre-school age is favorable for the formation of the child's self-esteem and is an important prerequisite for the origin of its adequacy. Self-evaluation is an assessment of the personality of one's self, of its capabilities, qualities, places among other people and their attitude towards it. Self-esteem is the result of integrated works in the field of self-knowledge and emotional and value attitude towards oneself. This particular formation of self-awareness serves as an important mechanism for selfregulation of behavior and activity, and, at the same time, is formed in the process of activity and communication of the child with other people. Senior preschoolers are noted for a number of age and psychological complexes and require an individual approach and subject-subject interaction with the immediate social micro-environment. In the older preschool age, the child's need for adult assessment is large, but the child's self-esteem begins to rely on the findings and conclusions that the child receives in the individual experience.

In the context of a transformational society and the modernization of the domestic educational space, the scientific study of the psychological conditions of the formation of self-esteem among older preschool children is a particularly urgent problem that requires its systematic solution in pre-school educational institutions.

Keywords: senior preschool age; an adequate self-esteem; a development of self-esteem; the psychological and pedagogical research.

П остановка проблеми. Проблема формування самооцінки дитини у старшому дошкільному віці є однією з пріоритетних у вітчизняній педагогічній науці.

Самооцінка починає утворюватися на рубежі раннього й дошкільного віку в процесі розвитку конкретних видів діяльності і поступово удосконалюється у напрямку збільшення адекватності і реалістичності.

Формування самооцінки дошкільника вирішуе проблему системоугворення особистісного ядра, що збалансовує індивідуальні можливості та розвиває здібності дитини. Вирішення цих завдань потребує вдосконалення системи дошкільної освіти, організації випереджувального навчання та формування в дошкільників адекватної самооцінки.

Мета статті - аналіз сучасних психологопедагогічних досліджень щодо розвитку адекватної самооцінки дітей старшого дошкільного віку.

Аналіз останніх досліджень і публікацій. Проблема формування самооцінки досліджувалася вітчизняними та зарубіжними науковцями на різних вікових періодах особистості.

Значна увага у вітчизняній психологопедагогічній науковій площині приділялася вивченню самооцінки саме в дошкільному віці (Б.Г. Ананьєв, Л.С. Виготський, М.І. Лісіна, Л.І. Уманець та інших), оскільки цей вік $є$ базовим 


\section{ПРОБЛЕМА РОЗВИТКУ АДЕКВАТНОӤ САМООЦІНКИ ДІТЕЙ СТАРШОГО ДОШКІЛЬНОГО ВІКУ УПСИХОЛОГО-ПЕДАГОГІЧНИХ ДОСЛДЖЕННЯХ}

для розвитку особистості дитини в цілому, іiі самосвідомості і самооцінки, усіх пізнавальних процесів, діяльності і спілкування дитини.

У контексті досліджень досягнень дошкільників в ігровій діяльності, їх самостійності та активності в ситуаціях успіху чи невдачі, вчені досліджували зв'язок самооцінки з домаганнями та мотивацією як показниками ціннісного ставлення до себе (О.Л. Кононко). Умови розвитку самоповаги, самоставлення та впливи пізнавальної активності на формування самооцінки досліджувалися в роботах Н.М. Дятленко, І.С. Литвиненко.

Виклад основного матеріалу. Дошкільний вік $є$ сприятливим для формування самооцінки дитини і виступає важливою передумовою зародження іiі адекватності.

Так, за даними Л.І. Уманець, самооцінка виступає як єдність раціонального й емоційного компонентів. У раціональному компоненті відбивається знання особистістю властивих ій особливостей, а в емоційному компоненті ставлення до них. Особливо цікавою в контексті нашого дослідження виступає лінія розвитку раціонального компоненту самооцінки, запропонована Л.І. Уманець [8].

До кінця дошкільноговіку, зазначає Л.І. Уманець, у процесі розвитку раціонального компоненту, виникає власна стійка самооцінка. Вона характеризується тим, що дитина усвідомлює власні практичні уміння, вчинки, моральні властивості, співвідносячи їх з вимогами дорослих [8].

На основі проведеного нами теоретичного аналізу літератури можна визначити, що одностайність у поглядах науковців щодо структури самооцінки спостерігається в думці про те, що найважливішим досягненням дошкільного віку є відокремлення загальної самооцінки від конкретної [8]. На думку, Г.О. Стадник самооцінка розвивається у напрямку від конкретної до загальної, при цьому найбільша адекватність та реалістичність притаманні саме конкретній самооцінці, а іiі реалістичність тим менша, чим більша міра узагальненості [7].

Надаючи вирішального значення дошкільному дитинству у формуванні самооцінки, Л.І. Уманець виділяє наступні їі рівні. Оскільки джерелом первинної самооцінки особистості, за даними науковця, виступає прийняте дитиною на віру ставлення дорослого, то неадекватна висока самооцінка може бути викликана постійним, часто необгрунтованим захвалюванням дитини. Невіра дорослих в можливості дитини призводить, в свою чергу, до формування негативного ставлення у дитини до себе і низької самооцінки. Саме у спілкуванні 3 близьким середовищем, оточуючими авторитетними людьми лежать основні причини, які зумовлюють особливості самооцінки дитини. Первинна самооцінка впливає на подальший процес їі становлення на більш пізніх етапах розвитку особистості [8].

Сучасний український педагог С.Г. Сарапулова зазначає, що адекватна самооцінка $\epsilon$ передумовою становлення активної життєвої позиції особистості. На її думку, адекватна самооцінка у різних людей має істотні відмінності. Так, “одні, адекватно оцінюючи себе та свої дії, насамперед звертають увагу на позитивне, а потім на негативне. Інші - навпаки". Тому логічним науковець вважає "поділ адекватної самооцінки на два підвиди: адекватна, наближена до заниженої та адекватна, наближена до завищеної” [6].

Видатний вітчизняний учений I.Д. Бех суттєвими складовими процесу виховання вважає розвиток рефлексії, вироблення у дитини уміння “подивитися на себе, як на іншого...” [2], а також формування у неї адекватної самооцінки, уміння “критично оцінити реальну себе та свої реальні дії у порівнянні з ідеалом” [1]. На підтвердження такої позиції іншими науковцями теж зазначено, що стійка конкретна самооцінка при наявності загальної позитивної самооцінки зумовлює типову схильність дошкільника до завищення уявлень про свої можливості, що відзначається багатьма дослідниками.

Іншої позиції дотримується О.Л. Кононко, наголошуючи на негативному впливові на розвиток дошкільника саме завищеної самооцінки, “... яка у майбутньому стане перешкодою у життєвому самовизначенні” [3].

Беручи до уваги позиції вітчизняних науковців, можемо зазначити, що найбільш негативний вплив на розвиток особистості дошкільника здійснює неадекватно занижена самооцінка або адекватна, наближена до заниженої самооцінка, оскільки гальмує активність, продукує розвиток невпевненості в собі, невміння ставити перед собою важкі цілі і досягати їх.

Вивчаючи проблему генезису самооцінки, дослідники стверджують, що самооцінка починає утворюватися на рубежі раннього й дошкільного віку в процесі розвитку конкретних видів діяльності і поступово удосконалюється в напрямку зростання адекватності та реалістичності. Самооцінка виступає результатом двох основних психологічних утворень: загальної самооцінки і конкретної самооцінки. Загальна самооцінка виникає в процесі спілкування з дорослим, а конкретна самооцінка зароджується 


\section{ПРОБЛЕМА РОЗВИТКУ АДЕКВАТНОЇ САМООЦІНКИ ДІТЕЙ СТАРШОГО ДОШКІЛЬНОГО ВІКУ У ПСИХОЛОГО-ПЕДАГОГІЧНИХ ДОСЛДЖЕННЯХ}

в процесі розвитку конкретних видів діяльності [5].

Розвиток психіки в онтогенезі пов'язаний 3 організацією конкретних форм діяльності. Це $\epsilon$ свідченням того, що на формування самооцінки в кожному віковомуперіоді переважний вплив має відповідний даному періоду провідний вид діяльності.

За даними українського психолога та педагога Г.С. Костюка, розвиток самооцінки можливий лише за умови виконання певної діяльності, усвідомлення своїх досягнень в ній, порівняння власних досягнень 3 досягненнями інших людей. Вчений зосереджує увагу на тому, що значний вплив на розвиток самооцінки дитини здійснюють оцінки з боку батьків, педагогів і однолітків [4].

Інший український психолог П.Р. Чамата формування самооцінки дошкільників пов'язував 3 ігровою діяльністю, а саме 3 колективними іграми 3 елементами змагань, що характеризуються наявністю різноманітних оцінювальних ситуацій [9].

Українські психологи С.П. Тищенко та Л.І. Уманець, досліджуючи формування самооцінки в сюжетно-рольовій грі, зазначають, що самооцінка дітей старшого дошкільного віку опосередкована оцінкою групи і залежить від ступеня відповідності даній оцінці. Збагачення змісту самооцінки на моральній основі, зростання iii реалістичності і рефлективності, виступає як передвісник підвищення ступеня відповідності самооцінки дитини оцінці її ігровою групою і одночасно як показник сформованості властивостей самооцінки, завдяки яким вона стає фактором удосконалення самого процесу гри та ігрових стосунків [8].

Український психолог В.К. Котирло, досліджуючи особливості самооцінки в контексті емоційного розвитку дитини, зазначає, що емоційно-ціннісне ставлення до себе утворюється на основі дитячих переживань, що виникають в процесі взаємодії з іншими дітьми, яку організовує дорослий на моральній основі. Також, на думку автора, важливим для формування емоційноціннісного ставлення дитини до себе $\epsilon$ оцінки дорослих. Виявлення задоволення чи незадоволення з боку дорослого щодо успіхів дитини в різних видах діяльності, іiї поведінки завжди викликають у дитини певні почуття, які в подальшому впливають на ії ставлення до себе i формування самооцінки.

Сучасний український психолог Т.О. Піроженко досліджує самооцінку дошкільників у процесі їх комунікативно-мовленнєвого розвитку. Науковець визначає самооцінку як окрему складову самоставлення разом 3 іншими такими його компонентами як самосвідомість, самопізнання, емоційне до себе ставлення, самоконтроль, саморегуляція. Дані поняття відображають “широкий спектр феноменів внутрішнього життя особистості, включаючи активність у сфері мовної взаємодії з соціумом".

На сучасному етапі українськими психологами та педагогами (Н.М. Дятленко, О.Л. Кононко та ін.) також приділяється належної уваги впливові оцінки дорослого на самооцінку дошкільника.

Зокрема, О.Л. Кононко вважає, що на етапі раннього і дошкільного дитинства “... центральною фігурою, навколо якої розгортається життя індивіда, є дорослий" [3]. У ході експериментальної роботи науковець з'ясувала, що малюки можуть зосереджуватися на власному позитивному досвіді, і не звертати уваги на небажані емоційні оцінки дорослих. Заохочення 3 боку дорослого і позитивна оцінка підвищували продуктивність діяльності дитини. Вказівки дорослого на недоліки або гальмували активність дитини, або ж, навпаки, виступали орієнтиром успішного пошуку, стимулом [3].

Дослідження О.Л. Кононко підтверджують, що дошкільний вік $є$ найбільш сприятливим для “становлення самосвідомості, домагання визнання дитини з боку значущих дорослих, елементарних форм адекватної самооцінки, початкових форм рефлексії, здатності пов’ язувати успіх не лише 3 позитивними оцінками авторитетного дорослого, а й з об'єктивними результатами кінцевого продукту праці та докладеними для його досягнення зусиллями" [3].

На основі проведеного нами теоретичного аналізу психологічної літератури, зазначимо, що формування самооцінки як багатоструктурного компоненту, можливе лише в процесі певної діяльності під впливом оцінок дорослих. Наприкінці дошкільного віку на самооцінку дитини починає здійснювати вплив не лише оцінка дорослого, а й однолітка та результати власної діяльності, що сприяє утворенню правильної диференційованої самооцінки і самокритичності. Виникає критичне ставлення до оцінки дорослого і однолітка.

Висновок. Отже, аналіз та узагальнення підходів і концепцій до вивчення проблеми самооцінки дошкільників свідчить, що окреслена проблематика $є$ особливо актуальною в умовах трансформаційного суспільства й модернізації вітчизняного освітнього простору і має тривалу науково-дослідницьку історію, залишаючись відносно малодослідженою. Багато вітчизняних і зарубіжних вчених розглядали аналізовану 
тематику крізь призму індивідуального підходу і суб'єкт-суб'єктної взаємодії з найближчим соціальним мікросередовищем. Дошкільний вік, для якого характерні динамічні зміни самосвідомості, є сприятливим для формування самооцінки дитини і виступає важливою передумовою зародження іiі адекватності.

\section{ЛІТЕРАТУРА}

1. Бех И.Д. Нравственность личности: стратегия становлення / И.Д. Бех. - Ровно: Редакц.-издат. отдел упр. по печати, 1991. - 146 с.

2. Бех І.Д. Особистісно зорієнтоване виховання / І. Д. Бех. - К.: ІЗМН, 1998. - 204 с.

3. Кононко О.Л. Ціннісне ставлення до себе / О.Л. Кононко // Мистецтво життєтворчості особистості. - К.: ІЗМН, 1997. - С. 96-126.

4. Костюк Г.С. Загальна характеристика онтогенезу людської психіки / Г. С. Костюк // Навчально-виховний процес і психічний розвиток особистості. - К.: Рад. шк., 1989. - С. 70-98.

5. Олійник О. О. Особливостіпсихокорекційної роботи у формуванні самооцінки старших дошкільників / О. О. Олійник // Проблеми емпіричних досліджень упсихології. - К.: Гнозис, 2008. - Вип. 1. - С. $347-352$.

6. Сарапулова Є.Г. Формування оптимальної самооцінки як передумова становлення активної життєвої позиції особистості / Є.Г. Сарапулова // Інноваційна система виховної роботи на основі продукування соціального розвитку особистості: матеріали Всеукр. наук.-практ. конф., 1 - 2 берез. 2001 р. - Луцьк, 2001. - С. 116 - 122.

7. Стадник Г. О. Вивчення пізнавальної активності дітей / Г. О. Стадник // Дошкіл. виховання. - 1992. - № 9. - С. $6-8$.

8. Уманець Л. І. Від самооцінки в грі - до пізнання себе / Л. І. Уманець // Дошкіл. виховання. - 1983. - № 4. - С. $20-21$.

9. Чамата П. Р. Самосвідомість та ії розвиток у дітей / П. Р. Чамата. - К.: Знання, 1995. - 48 с.

\section{REFERENCES}

1. Bekh, I.D. (1991). Nravstvennost lichnosti: strategiya stanovlennya [Morality of the individual: the strategy of becoming]. Rovno: Redakts.-izdat. otdel upr. po pechati, 146 p. [in Russian].
2. Bekh, I.D. (1998).Osobystisno zoriientovane vykhovannia [Personality oriented education]. Kyiv: IZMN, 204 p. [in Ukrainian].

3. Kononko, O.L. (1997). Tsinnisne stavlennia do sebe [Valuable attitude towards oneself]. Mystetstvo zhyttietvorchosti osobystosti [The Art of Life Creative Personality]. Kyiv: IZMN, pp. $96-$ 126. [in Ukrainian].

4. Kostiuk, H.S. (1989). Zahalna kharakterystyka ontohenezu liudskoi psykhiky [The general characteristics of ontogenesis of the human psyche]. The educational process and mental development of personality. Kyiv: Rad. shk., pp. 70 - 98. [in Ukrainian].

5. Oliinyk, O.O.(2008). Osoblyvosti psykhokorektsiinoi robotyu formuvanni samootsinky starshykh doshkilnykiv [The peculiarities of psycho-correction work in the formation of self-esteem of senior preschool children]. The problems of empirical research in psychology. Kyiv: Hnozys, Vol. 1, pp. 347 - 352. [in Ukrainian].

6. Sarapulova, Ye.H. (2001). Formuvannia optymalnoi samootsinky yak peredumova stanovlennia aktyvnoi zhyttievoi pozytsii osobystosti [The formation of optimal self-esteem as a prerequisite of the formation of an active life position of the individual].Innovatsiina systema vykhovnoi roboty na osnovi produkuvannia sotsialnoho rozvytku osobystosti: materialy Vseukr. nauk.-prakt. konf., 1 - 2 berez. - An innovative system of educational work on the basis of production of social development of personality: Proceedings of the Ukrainian Scientific and Practical Conference, the 1st-2 ${ }^{\text {nd }}$ of March, (pp.116-122). Lutsk. [in Ukrainian].

7. Stadnyk, H.O. (1992). Vyvchennia piznavalnoi aktyvnosti ditei [Study of cognitive activity of children]. Preschool education. No. 9, pp. 6-8. [in Ukrainian].

8. Umanets, L.I. (1983). Vid samootsinky v hrido piznannia sebe [From self-esteem in the game to self-knowledge]. Preschool education. No. 4, pp. $20-21$. [in Ukrainian].

9. Chamata, P. R. (1995). Samosvidomist ta yii rozvytok $u$ ditei [Self-awareness and its development in children]. Kyiv: Znannia, 48 p. [in Ukrainian].

Стаття надійшла до редакції 28.08.2018

\section{$\cos 8080 \cos 8080 \cos 80$ socicos}

"Жодне бажання не дається тобі оқремо від сили, що дозволяє його здійснити". Річард Dейвіс Бах американсъкий письменник

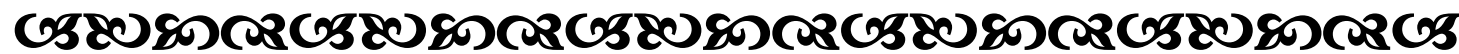

